\title{
TOWARDS A LISTED REAL ESTATE INVESTMENT VALUATION MODEL
}

\author{
Douw GB Boshoff \\ Department of Construction Economics, University of Pretoria
}

Accepted: March 2013

\begin{abstract}
This paper presents a Listed Real Estate Investment Valuation Model that was developed to investigate the movement in indirect real estate investment through the consideration of the underlying assets of property loan stock companies. Specific reference is given to information that is made available to shareholders by way of annual financial statements in order to determine the extent to which shareholders can make investment decisions based on this information. The study enhances the knowledge of direct vs. indirect real estate investment behaviour and provides more insight into price discovery in the property sector.
\end{abstract}

Key words: valuation models, indirect property, listed property, price discovery

JEL: G120, 170, 300320

\section{1 \\ Introduction}

Stock-market-listed property investment funds bring the two different investment classes, i.e. the stocks and bond market and the property market, together as comparable entities. Previous literature has shown that price discovery takes place in the listed property market, which might be an indication of market activity also in the direct property market. The objective of this paper is to develop a model that can measure the relationship between the share prices of Property Loan Stock (PLS) companies and their underlying assets, by investigating specifically the information provided to shareholders by means of annual financial statements.

In order to develop such a model, the stock exchange listed PLS companies in South Africa are taken as case study, with the aim to formalise the Listed Real Estate Investment Valuation Model (LREIV model).

\section{2}

\section{Null hypothesis and alternative hypothesis}

In order to formalise the LREIV model, it is necessary to consider the null hypothesis, which could be stated as follows:
$S P_{i} x N S_{i} \neq \beta_{0}+\beta_{1} P_{i}+\beta_{2} T A_{i}+\beta_{3} D T_{i}+\beta_{4} T O_{i}$ $+\beta_{5} O P_{i}+\beta_{6} T C_{i}+\beta_{7} I D_{i}+\beta_{8} L T L_{i}+\beta_{9} E_{i}+\epsilon_{i}$ and the alternative hypothesis as:

$S P_{i} \times N S_{i}=\beta_{0}+\beta_{1} P_{i}+\beta_{2} T A_{i}+\beta_{3} D T_{i}+\beta_{4} T O_{i}$ $+\beta_{5} O P_{i}+\beta_{6} T C_{i}+\beta_{7} I D_{i}+\beta_{8} L T L_{i}+\beta_{9} E_{i}+\epsilon_{i}$ Where:

$\beta_{0}=$ Y intercept

$S P_{i}=$ Average share price at observation $i$

$N S_{i}=$ Average no. of shares issued at observation $i$

$P_{i} \quad=$ Prime interest rate at observation $i$

$T A_{i}=$ Total assets at observation $i$

$D T_{i}=$ Deferred tax at observation $i$

$T O_{i}=$ Turnover at observation $i$

$O P_{i}=$ Operating profit at observation $i$

$T C_{i}=$ Total cost shown at observation $i$

$I D_{i}=$ Debenture interest paid at observation $i$

$L T L_{i}=$ Leverage due to long term debt at observation $i$

$E_{i}=$ Equity at observation $i$

$\epsilon_{i}=$ Random error in Y for observation in $i$ Source: Author

If the null hypothesis could be rejected, that the mentioned variables together do not explain the movement in the market capitalisation (share price $\mathrm{x}$ number of shares issued), or that any of the individual variables better explains the market capitalisation, then the alternative hypothesis could be accepted 
that the movement in market capitalisation could be explained by the movement in the mentioned variables. This would imply that shareholders of PLS companies have sufficient information available from financial statements in order to make investment decisions.

\section{3}

\section{Data use}

Data on the listed property funds was obtained from McGregor BFA, a company specialising in the capturing of financial information of companies listed on the Johannesburg Stock Exchange in a standard format, and included:

- Share price performance;

- Financial statements;

- Shareholding;

The data for evaluation of the PLS companies comprises panel data; which is structured as a short panel with annual data over a period of 10 years (2001 to 2010) for 19 companies. The panel is balanced for most of the observations, but some of the companies under investigation do not include the whole time frame, causing the panel to be unbalanced. Due to the time series component of the data, the observations were deflated by CPI before testing, in order to ensure that inflationary effect did not distort the findings of the study. For regression purposes the first difference of the company variables were taken.

\section{4}

\section{Related literature}

Glascock, Lu and So (2000:178) mention that the relationship between real estate investment trusts and unsecuritised real estate is most controversial. On the one hand, some studies suggest that these types of real estate are unrelated (see Gyourko and Linneman, 1988; Scott, 1990; Ross \& Zisler, 1991). Newell and Keng (2005:8) also found that property is only a small contributor to the performance of listed property trusts (LPTs) in Australia. They found that LPTs correlated less with stocks over the period of 1985 to 2004 (Newell \& Keng, 2005:4), and that LPTs correlated more closely with bonds over this perio (p. 5). The study furthermore noted that unlisted property trusts and property syndicates are more likely to perform like their underlying direct property assets (p. 8). This is an indication that the structure of the vehicle in which the assets are held might have an influence on the performance and the predictability of the underlying assets. A number of other studies also document that direct and indirect real estate are linked by the same common factors (see Chan, Hendershott \& Sanders, 1990; Giliberto, 1990; Gyourko \& Keim, 1992).

Doppegieter and Rode (2002:2) mention that also in South Africa, property securitisation is still in its infancy and has not yet reached a critical mass.

The literature therefore indicates that securitised real estate investment and direct real estate investment are still relatively unexplored in both their application and the available knowledge of application.

Booth and Marcato (2004:147) state that information from the indirect real estate market could be useful in understanding the direct real estate market in two ways:

- Real estate indices could be developed from traded investments - which are closer to a transaction-based index rather than objective valuations.

- This could enable a more timely flow of information.

"Unfortunately, property values cannot be determined by quick reference to the stock market, but have to be determined independently" (Hager \& Lord, 1985:23). Although this statement questions the possibilities of this research, a number of studies do find useful information in the listed property market. It is, however, a cautionary note that there are other influences on listed property that are not evident in direct property. If these are not taken into consideration, they could obscure the information on direct property that could be obtained from listed property investment vehicles. It was also mentioned earlier that the different structure of vehicles may also show different results, and therefore special care should be taken when assessing listed property for the purpose of analysing direct property behaviour. Yavas and Yildirim (2011) investigated the price discovery in real estate markets. As in most other literature investigated, they concentrate on the returns in REITs 
against the returns in the net asset values (NAV). It was found that that REITs are leading, causing changes in the NAV returns to follow. The same was found by Barkham and Geltner (1995) in American as well as British property markets, using asset value indices for both. This confirms the possibility to utilise information from the listed property market for price discovery purposes in the direct property market.

Various studies consider the relationships between direct and indirect property investment behaviour. It was found that listed property shares show various similarities in behaviour to direct property investment. However, listed property shares alsoshare many similarities with other investments, like index-linked gilts (Hager \& Lord, 1985:23), the general stock market and bond returns (Giliberto, 1990:259), other securities (Sagalyn, 1990:209) or exchange-traded non-real estate shares (Ling \& Naranjo, 1999:483 \& 505-506). Peterson and Hsieh (1997:322) on the other hand, found that most of the evidence regarding REIT performance shows that REITs tend to either outperform or perform about the same as common shares. It is evident from these studies that, due to their structure, listed real estate shares have similarities to other types of investments, causing distinct differences to direct real estate. Lizieri and Satchell (1997:12) show that property shares also exhibit a strong "contemporaneous correlation" with overall equity performance. Lee and Stevenson (2007:551) found strong links between REITs and value shares, but they state that there remain sufficient differences in their return behaviour and driving forces for the two sectors to retain a level of distinctiveness, providing portfolio optimisation opportunities for which the one is not substitutable with the other. Boudry, Coulson, Kallberg \& Liu (2011: 13-14) found that although REITs have characteristics of stocks and bonds, they also share characteristics with the underlying real estate and REITs and real estate markets adjust to each other in the long term.

There are, therefore, some clear similarities between direct and indirect real estate behaviour, as well as some distinct differences. It is assumed that listed real estate funds are influenced by factors similar to those influencing direct real estate. Yet the correlation between indices of listed funds and direct property investment is questionable (Giliberto, 1990:259). Giliberto (1990:262) showed that stock and bond market movements heavily influence the performance of EREITs, but have a relatively minor effect on direct real estate investment. However, if financial market effects are disregarded, a strong positive correlation becomes evident. This suggests the presence of a common factor, or factors, in both sets of returns. Glascock et al. (2000:178179) indicated that REITs and unsecuritised real estate should be co-integrated. However, co-integration between REITs and stock markets may be absent when the key gains in securitised real estate come from management and risk-sharing rather than the underlying asset of real estate per se. This suggests that company structure may influence the level of co-integration between direct and indirect real estate. Of particular importance in this regard is the difference between the PLS structure used in South Africa and the REIT structure used in various other markets. Further evidence that the structure of the investment vehicle that owns the direct property rights could influence the perceived real estate performance, is found by Glascock et al. (2000:177-178). They indicate that as the REIT market continues to develop, institutional investors are becoming more comfortable in this form of real estate investment, and institutional holdings of REIT IPOs have increased from less than 10 per cent before 1990 to 41,7 per cent after 1990 . This increase in institutional investment in the REIT market is partly facilitated by the tax reform act of 1993. The tax reform act allows more institutional investment without jeopardising the trust's tax-favoured status. These structural changes are important to portfolio management, because they may allow REITs to behave more like traditional (small-cap) shares than real estate. The evidence of tax structures influencing indirect real estate, further supports the presumption that REITs and PLSs may perform differently, as their tax treatment is different.

Institutional as well as individual investors often perceive investment in listed property vehicles or real estate funds such as PLSs or 
PUTs, as equivalent to investment in direct real estate, while retaining a degree of liquidity that is unavailable from other forms of real estate investment (Giliberto, 1990:259).

The studies mentioned above show that there are certain correlations between the behaviour of listed funds and direct real estate, but also indicate that real estate shares have similarities with the stock market in general.

Chan, Leung and Wang (1990:432) showed that three factors consistently drive both real estate and stock market returns: changes in the risk structures, term structures and unexpected inflation.

According to Gyourko and Keim (1993:39), real estate shares traded on the New York and American stock exchanges reflect changes in real estate market fundamentals more timeously than a widely used appraisal-based system. They mention two findings that are of particular relevance:

- There is no significant contemporaneous correlation between EREIT and appraisal series returns.

- EREIT returns are significantly positively correlated with broader stock market returns.

These findings have led many to conclude that share prices are not reliable guides to real estate values. They show, however, that the stock market provides reliable return measures for one of the most important, yet least studied and understood asset categories. They show that decisions based on movements in appraisal-based indexes rely, in large part, on out-dated information. The stock market, however, provides a reliable measure of real estate conditions.

Fisher, Geltner and Webb (1994:137-160) consider the history of commercial property values by comparing different methods of constructing commercial property value indices and return series. Three types of indices were examined:

1) Indices that attempt to reconstruct property market values by "unsmoothing" appraisalbased indices;

2) Indices that trace average ex post transaction prices of commercial properties over time; and

3) An index based on unlevering REIT share prices.
They found that the REIT index shows more volatility than the other indeces, and leads by up to two years, indicating that market changes could be identified much quicker in the listed property sector. In the long term, however, it shows the same pattern of returns.

Booth and Marcato (2004:147) found that the two main causes of the difference between the performance of direct real estate and real estate share indices were first the smoothing of valuation based indices and, second, the gearing ratio of property shares or REITs indices. It was found that there was a close relationship between de-geared indirect market indices and unsmoothed direct market indices, and that there was a larger degree of causality running from the indirect to the direct market. Booth and Marcato (2004) mentioned that direct real estate indices do not measure the performance of underlying transaction prices properly because they are based on valuations, and therefore may be subject to valuation smoothing. Indirect real estate indices do not properly measure the value investors put on the underlying assets of real estate companies, because real estate companies are geared. They furthermore note that the analysis of the relationship between annual returns from direct real estate and annual returns from real estate shares suggests that de-geared real estate share returns have useful information content that could help one to understand performance in the direct real estate market. It is shown that when direct real estate data is unsmoothed, measures of dependency between the direct and the de-geared indirect market strengthen considerably, and if it is assumed that unsmoothed direct real estate returns better reflect underlying transaction prices than direct real estate data, the results suggest that data from the market for real estate shares could be useful for filling the gaps in direct market series.

Doppegieter and Rode (2002:2) explain that the dividend yields and capitalisation rates of PUTs, when used for valuation, are not based on the same variables, and differences should be expected. They state that PUT dividend yields provide a better indication of commercial property values in South Africa than capitalisation rates. 
The studies mentioned so far mostly consider the relationship between direct real estate investment and investment through listed vehicles by way of the similarities in the return achieved. The factors driving the return are discussed and the effect on share prices is tested and used to construct indices to predict return behaviour rather than value. There is also evidence of similarities between real estate share behaviour and the behaviour of other shares. Again, discussion is largely based on returns rather than actual share prices or value. No evidence of studies conclusively comparing the value of shares directly to the value of the underlying real estate could be found.

Chan et al. (1998:357) indicate that ownership structure (as well as the resulting shareholder activism) has a direct impact on the ability of shareholders to monitor management activities. In addition, this monitoring ability provided by institutional investors could affect a firm's value. According to the authors, several studies further show that the investment strategy of institutional investors has an impact on share returns and their autocorrelation.

Chan et al. (1998:357-358) continue, that fewer institutional investors invest in REIT shares than in the general stock market. In addition, REIT shares with a higher per centage of institutional ownership perform better than other REIT shares with fewer (or no) institutional investors. It therefore appears that the participation of institutional investors increases the control and monitoring ability of shareholders, and hence the value of REIT shares. Furthermore there are some large institutional investors who concentrate their investments in the REIT stock market. Consequently, the monitoring and control aspects of those REITs must be improving, as institutional investors normally have the expertise and are more willing to spend resources to monitor the companies in which they invest (Chan et al., 1998:372).

Downs and Güner (1999:518) stated that problems associated with observing the value of the underlying asset in real estate securities are frequently cited by practitioners and academics. Brennan (1990:727-728) refers to this as a latent-asset problem, i.e., the information acquisition problem of investors when the value of some assets is not observable.

From the above it appears that securitised real estate is a good alternative to direct real estate, from an investment perspective as well as an information supply perspective, but the differences should be understood. This substitution appears to be increasing, indicating the importance of understanding the relationship between securitised and direct real estate, but also that information availability could increase over time. Wilson and Zurbruegg (2003:205206) indicate that, with the emergence of securitised real estate as a viable alternative for institutional investors in the late $1980 \mathrm{~s}$ and early $1990 \mathrm{~s}$, the question whether the direct and indirect property markets are driven by different forces has become an integral part of the research debate. They state that a shortcoming in the literature appears to be a lack of the effective identification of those factors that have a lasting effect on moving property markets (permanent components) and those factors that do not (transitory components). Identifying those factors is important because:

- Institutional investors have both long- and short-term goals driven by their strategic and tactical asset allocation objectives. Isolating the objectives would provide them with more effective information on how to adjust their portfolios;

- Securitised property markets have their underlying assets in the direct property sector. It is therefore reasonable to suppose that the permanent driving forces should be the same in both, although the transitory components may differ;

- Isolating permanent vs. transitory components will help identify the sort of controls that monetary and fiscal authorities have over domestic real estate, which again have important ramifications for institutional investors.

It is apparent from the above that the behaviour of listed property share prices is influenced by the involvement of institutional investors, and also by the amount of information that is available to them when they are making investment decisions. This was also found by Gillan and Starks in two separate studies (Gillian \& Starks, 1999; Gillian \& Starks, 2000). 


\section{5 \\ Multiple regression of identified data}

The literature discussed in section 4 indicated that there is information that has similarities in the listed as well as the direct property market. This indicates that there should be similarities in the direct property market's behaviour, as seen in the assets of the companies, as well as the share prices. The difference between direct property and the PLS company is, inter alia, that the PLS consists of a portfolio of properties, opposed to individual properties that are directly measurable when directly invested, and the PLS company is geared through financing activities, which obscures the movement of share prices in relation to the asset holdings, which financing is not taken into consideration with direct property values. Although there are other differences as well, such as the influence of stock market sentiment and irrational behaviour of investors, these do not fall under the scope of this study. The variables mentioned in the hypothesis were selected through the use of artificial intelligence techniques with the aim to achieve the following:

Prime interest rate - Influence expenses at different levels of gearing

Total assets - Provides the total value of the portfolio of assets

Deferred tax - Proxy for capital growth

Turnover - Proxy for the quality of the portfolio, i.e. total income derived

Operating profit - Proxy for effectiveness of company i.t.o. income

Total cost shown - Proxy for effectiveness of company i.t.o. expenses

Debenture interest paid - Proxy for cash return by shareholders

Leverage due to long term debt - Proxy for financing activities to explain gearing

Equity - Proxy for the value of the company to shareholders

The results of the multiple regression, where the above variables were used as explanatory variables and the average market capitalisation was used as dependent variable, is shown in Annexure 1. From the model summary, the adjusted $\mathrm{R}$ square value is indicated at 0.815 . It is however necessary to test the influence of outliers on the model. By excluding all outliers outside two standard deviations, the adjusted $\mathrm{R}$ square change to 0.814 , with the F-value reducing from 30.862 to 26.353 .

From the descriptive statistics the number of observations in the pooled data could be seen to vary between different variables. This is due to information availability and in line with literature on information deficiency which might have an influence on the results. The missing values could be due to the fact that they are indeed zero, or are excluded from the financial statement item due to a different accounting policy in that specific year, or omission for whatever other reason. The regressions done thus far were done by excluding missing variables on a case-by-case basis, i.e. by accepting the other variables in that observation would sufficiently explain the dependent variable. It is, however, necessary to test the effect if the regression is done by excluding an entire observation, whether it has any missing observations for any of the variables in it. Of most concern in doing so, is the number of observations in the variable Interest Paid - Debentures, which has substantially lower observations. By excluding all observations where this variable is missing, the number of observations is significantly affected. For this reason, the effect is tested by excluding 'Interest Paid - Debentures' from the model, thereby having all observations of the balance of the variables available. Alternatively they could be included, reducing the number of observations as mentioned. By excluding Interest Paid - Debentures first from the model where missing values are excluded case-by-case, and outliers outside two standard deviations are excluded, the $\mathrm{R}$ square reduces from 0.814 to 0.804 , but the F-value increases from 26.353 to 49.666 . The critical F-value in this case is 5.01 at the 0.01 level of significance. By including Interest Paid Debentures, but excluding all observations with missing observations in any variable, the number of observations is reduced to 43 , and result in an $\mathrm{R}$ square of 0.618 with an F-value of 7.788. The critical F-value for this is 4.25 at the 0.01 level of significance. By excluding the Interest Paid - Debentures variable, the remaining observations for the balance of the variables with no missing data, are 84 . In this 
case the $\mathrm{R}$ square is 0.539 with an F-value of 13.143. The critical F-value in this case is 4.99 at the 0.01 level of significance. By excluding Interest Paid - Debenture, it could therefore be accepted that, with the information available on debenture loans of the coefficient of determination reducing slightly, the level of significance increasing substantially, the hypothesis could be accepted that this variable does not belong in the model. The model is also best described by excluding missing values on a case-by-case basis, rather than excluding the entire observation. These results are shown in Annexure 2.

For the purposes of the hypothesis, the null hypothesis is tested that the individual items better explain the average market capitalisation than the items combined in the multiple regression. The individual items are regressed against average market capitalisation and the hypothesis is tested based on the F-values of these individual regressions. The results are shown in Table 1.

One of the variables could be accepted at the 0.05 level of significance and one at the 0.01 level. The $\mathrm{R}$ square as well as the $\mathrm{F}$ values in relation to the respective critical $F$ values suggest that the multiple regression is better at explaining the market capitalisation than the individual regressed variables. Therefore, the null hypothesis that any of the individual simple regressions could equally or better explain the movement in the average market capitalisation could be rejected. The alternative hypothesis is therefore accepted that the multiple regression better explains the movement in the average market capitalisation than any of the individual regressions.

Table 1

Comparison of simple regression to multiple regression ${ }^{\mathrm{a}}$

\begin{tabular}{|l|c|c|c|c|l|}
\hline \multicolumn{1}{|c|}{ Variable } & R Square & F & $\begin{array}{c}\text { Critical F } \\
\mathbf{0 . 0 5}\end{array}$ & $\begin{array}{c}\text { Critical F } \\
\mathbf{0 . 0 1}\end{array}$ & \multicolumn{1}{|c|}{$\begin{array}{c}\text { Reject } \text { Accept Ho } \\
\text { Accept @ .01 }\end{array}$} \\
\hline Multiple regression & .804 & 49.666 & 1.57 & 2.62 & Accept .07 \\
\hline Total Assets & .598 & 175.384 & 63.1 & 253 & Accept @ .05 \\
\hline Deferred Tax & .192 & 26.403 & 63.0 & 253 & Reject \\
\hline Leverage - long term \% & .036 & 5.029 & 63.0 & 253 & Reject \\
\hline Equity & .720 & 296.268 & 63.1 & 253 & Accept @ .01 \\
\hline Turnover & .214 & 32.887 & 63.1 & 253 & Reject \\
\hline Operating Profit & .240 & 37.927 & 63.1 & 253 & Reject \\
\hline Total Cost Shown & .002 & 1.283 & 63.1 & 253 & Reject \\
\hline Interest Paid - Debentures & .277 & 25.565 & 62.8 & 252 & Reject \\
\hline
\end{tabular}

a. Dependent Variable: Average market cap

In order to confirm that the alternative hypothesis is not incorrectly accepted, the variables are also tested for multicollinearity, heteroskedasticity and serial- or autocorrelation.

Multicollinearity is tested by first considering the correlation between the independent variables. Total Assets and Equity stand out to be quite highly correlated, with a correlation of 0.84. The variance-inflating factors (VIF) shown in Annexure 1, are indicated at 6.381 and 7.002 for these two variables respectively, which, although start out on the high side, are considered not to be severe. The eigenvalues of the model have minimum and maximum figures of 0.011 and 4.578 , indicating a $k$-value of 416 and a resultant CI-value of 20.274. All these tests indicate that a moderate to high multicollinearity is present, but it is still substantially below a severe level, where the extent to which it affects the model makes the results questionable. The levels of multicollinearity are therefore considered to be acceptable without needing any transformation.

Testing for heteroskedasticity was done by way of a Goldfeld-Quandt test, where it is tested if $\lambda$ is greater than the critical F-value, in which case heteroskedasticity is present. For this purpose, two datasets were established, each with $(n-c) / 2$ number of observations, with $c$ chosen as 30 for the total of 126 observations $(n)$, leaving each dataset for the test with 48 observations. $\lambda$ is then determined by the equation: 


$$
\lambda=\left(\mathrm{RSS}_{\mathrm{H}} / \mathrm{DF}_{\mathrm{H}}\right) /\left(\mathrm{RSS}_{\mathrm{L}} / \mathrm{DF}_{\mathrm{L}}\right)
$$

This resulted in the value of $\lambda$ being 2.502 . The critical values of $F$ are 1.91 at the 0.05 level of significance and 2.52 at the 0.01 level of significance. This indicates that the hypothesis of homoscedasticity is rejected at the 0.05 level of significance, but the test failed to reject the hypothesis at the 0.01 level. It is however an indication that some level of heteroskedasticity is suspected. Because it is not confirmed at the 0.01 level, it is sufficed with a note of possible remedial measures, which are left for further research. The data transformation was done by way of taking the first difference for the time-series data, but growth is an exponential pattern, not a straight line. It is therefore expected that the higher difference figures in bigger companies as well as later growth periods, are causing some level of heteroskedasticity. In order to resolve this, it should be considered to take the per centage growth for analysis, rather than the first difference. The level of heteroskedasticity is however not considered to be so severe that the findings of the study are jeopardised.

Serial correlation is tested by way of a Durbin-Watson test. As indicated in Annexure 2, the Durbin-Watson value for the model is 2.121. The significance points of the DurbinWatson $d$ statistic are $\mathrm{d}_{\mathrm{L}}=1.552$ and $\mathrm{d}_{\mathrm{U}}=$
1.849 at the 0.05 of significance and $\mathrm{d}_{\mathrm{L}}=$ 1.433 and $\mathrm{d}_{\mathrm{U}}=1.725$ at the 0.01 level. This indicates the range for rejecting $H_{0}$ of positive or negative autocorrelation to be between 1.849 and 2.151 at the 0.05 level and 1.725 and 2.275 at the 0.01 level. This indicates that the hypothesis of negative or positive autocorrelation to be present could be rejected at the 0.01 level and it is therefore accepted that autocorrelation is not present. In order to ensure the test is accurate, it is worth mentioning that the data ordered for the variables is in time-series order, i.e. all observations per company grouped together in date order. This is important to test the effect of autocorrelation over time; otherwise the Durbin-Watson $d$ statistic could provide a false output.

As mentioned in section 4, price discovery was found in the listed sector, which could provide information on the non-listed property sector. The regression done thus far proved that there are price discovery possibilities, but it needs to be determined in which direction the price discovery takes place. For this purpose a Granger causality test was performed between Total Assets and Average Market Capitalisation for 1, 2, 3, 4 and 5 time lags of one year each. The F-values for this is shown in Table 2.

Table 2

Granger causality between total assets and average market capitalization

\begin{tabular}{|c|c|c|c|c|c|c|}
\hline \multirow[b]{2}{*}{ Dependent } & \multirow{2}{*}{$\begin{array}{c}\text { Number of } \\
\text { Lags }\end{array}$} & \multirow[b]{2}{*}{ F-value } & \multicolumn{4}{|c|}{ Critical values } \\
\hline & & & 0.25 & 0.1 & 0.05 & 0.01 \\
\hline \multirow{5}{*}{ Total assets } & 1 & 6.409 & & 9.80 & 63.10 & 253.00 \\
\hline & 2 & 3.739 & 3.47 & 9.48 & 19.50 & 99.50 \\
\hline & 3 & 3.314 & 2.47 & 5.14 & 8.55 & 26.20 \\
\hline & 4 & 6.189 & 2.08 & 3.79 & 5.69 & 13.70 \\
\hline & 5 & 3.791 & 1.88 & 3.15 & 4.44 & 9.24 \\
\hline \multirow{5}{*}{$\begin{array}{l}\text { Average market } \\
\text { capitalization }\end{array}$} & 1 & 137.648 & & 9.80 & 63.10 & 253.00 \\
\hline & 2 & 69.043 & 3.47 & 9.48 & 19.50 & 99.50 \\
\hline & 3 & 32.441 & 2.47 & 5.14 & 8.55 & 26.20 \\
\hline & 4 & 34.640 & 2.08 & 3.79 & 5.69 & 13.70 \\
\hline & 5 & 20.873 & 1.88 & 3.15 & 4.44 & 9.24 \\
\hline
\end{tabular}

The green shaded areas in Table 2 show where the F-value exceeds the critical F-value for the various time lags and at different levels of significance. The F-values indicate that there is better evidence for Total Assets to granger cause Average Market Capitalisation than there is for Average Market Capitalisation to cause Total Assets. This suggess that price discovery may take place in the direct property market rather than in the listed property 
market. This is in contrast to the findings of both Yavas and Yildirim (2011) and Barkham and Geltner (1995) as discussed in section 4. The reason may be the data frequency used for the estimate, keeping in mind that share prices change on a daily basis, while the data used is only the annual weighted average. Because the total assets of the PLS companies are not revalued more frequently, the test cannot be performed on the actual valuations as performed here. It should however be considered to perform the test on index data, similar to the mentioned literature, taking into consideration more frequently observed direct property data. If the findings of Yavas and Yildirim (2011) and Barkham and Geltner (1995) are also applicable here, it would suggest that price discovery takes place in the short term in the listed sector, but over longer periods, prices are corrected by direct property behaviour.

From the above it can be seen that the share prices could be predicted by the changes in different company variables, given the company structure. The value of the market capitalisation, which is the product of the share price and the number of shares, can be written in terms of the LREIV model as:

\begin{tabular}{|c|c|c|}
\hline $\mathrm{SP}_{\mathrm{i}} \mathrm{x}$ & $\mathrm{NS}_{\mathrm{i}}$ & $\beta_{0}+\beta_{1} \mathrm{P}_{\mathrm{i}}+\beta_{2} \mathrm{TA}_{\mathrm{i}}+\mathrm{f}$ \\
\hline Wher & & \\
\hline & $=Y$ & intercept \\
\hline & $=A v$ & verage share price at observation $i$ \\
\hline$N S_{i}=$ & $\begin{aligned}= & A v \\
& o b\end{aligned}$ & $\begin{array}{l}\text { verage no. of shares issued at } \\
\text { bservation } i\end{array}$ \\
\hline$E_{i}$ & $=E q$ & quity at observation $i$ \\
\hline$D T_{i}=$ & $=D$ & eferred tax at observation $i$ \\
\hline$L T L_{i}=$ & $\begin{aligned}= & L e \\
& o b\end{aligned}$ & $\begin{array}{l}\text { everage due to long term debt at } \\
\text { bservation } i\end{array}$ \\
\hline$T O_{i}$ & $=T u$ & urnover at observation $i$ \\
\hline$O P_{i}$ & $=O p$ & Pperating profit at observation $i$ \\
\hline$T C_{i}=$ & $=T o$ & otal cost shown at observation $i$ \\
\hline$P_{i}$ & $=\operatorname{Pr}$ & rime interest rate at observation $i$ \\
\hline & $\begin{array}{l}=R a \\
\text { : Author }\end{array}$ & $\begin{array}{l}\text { andom error in Y for observation in } i \\
\text { or }\end{array}$ \\
\hline
\end{tabular}

In conclusion, although the alternative hypothesis stated in section 2 could be accepted, it was shown that market capitalisation could be explained at a higher level of significance if the interest paid on debentures was excluded from the model. This is considered due largely to the limited information that is available in this variable, pointing to some information deficiency in the financial statements.

\section{6}

\section{Listed real estate investment valuation model tested}

In order to test the model, three transactions that took place in the period 2010/2011 will be considered:

- The purchase of 50 per cent of the V\&A Waterfront by Growthpoint for R4 858500 000;

- Takeover of the Attfund portfolio by
$\beta_{3} \mathrm{DT}_{\mathrm{i}}+\beta_{4} \mathrm{TO}_{\mathrm{i}}+\beta_{5} \mathrm{OP}_{\mathrm{i}}+\beta_{6} \mathrm{TC}_{\mathrm{i}}+\beta_{7} \mathrm{LTL}_{\mathrm{i}}+\beta_{8} \mathrm{E}_{\mathrm{i}}+\epsilon_{\mathrm{i}}$ Hyprop Properties;

- Listing of the Investec Property portfolio on the JSE.

These transactions provide an opportunity to test the LREIV model by comparing the influence of the transactions on the portfolio value, and on the share price movements for the period over which the transactions were concluded.

\section{a Growthpoint acquisition of 50 per cent interest in $V \& A$ Waterfront}

On 13 December 2010, Growthpoint published a cautionary announcement for its shareholders trading with its shares, due to negotiations that were under way and might influence their share price. The cautionary announcement was renewed on 26 January 2011. At that stage the Growthpoint share price started to decline (see Figure 1), but so did the PLS index. So it is difficult to say to what extent this transaction was responsible for the change in share price. Growthpoint represents approx. 31 per cent of the PLS index, so a change in Growthpoint could influence the index as a whole, but the movement in the index seemed more severe than that caused by Growthpoint.

On 14 February 2011 Growthpoint announced that it had entered into an agreement to acquire a 50 per cent interest in the V\&A Waterfront with the Government Employees Pension Fund (GEPF) represented by the Public Investment Corporation (PIC), subject to certain suspensive conditions that had to be fulfilled. The information provided to shareholders included some details of the property in terms of its use, 
size, etc. and its financing, which was said to have been done on credit to cover the equity portion of the sellers, and by preference shares to cover the debt portion of the sellers. For the present purpose, the financing is considered as debt, as both portions basically imply debt.

On 9 June 2011 it was published that the transaction was finalised and all suspensive conditions had been met.

Figure 1

Growthpoint share price vs J203

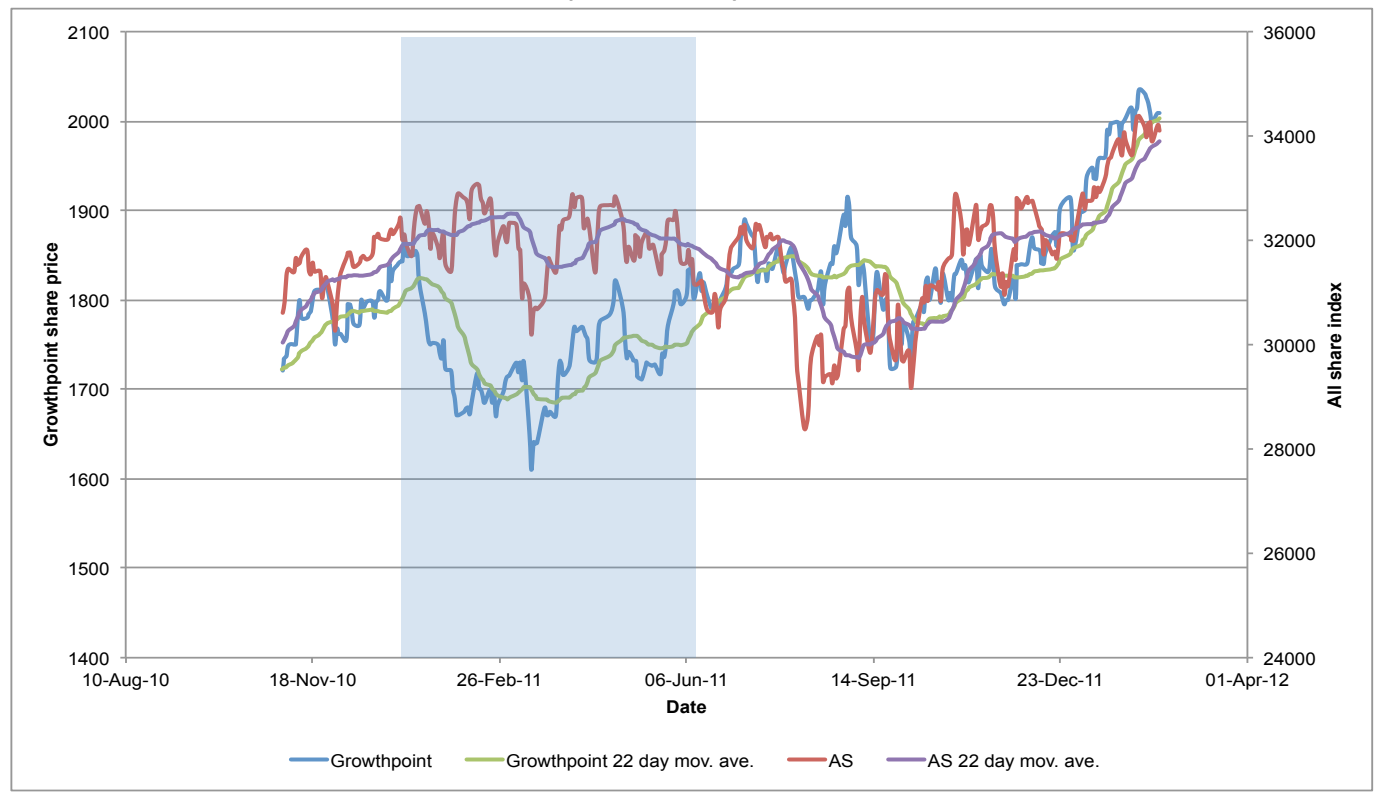

If the share price movement of Growthpoint is compared to the All Share Index (J203), as shown in Figure 1, it can be seen that there is a very close co-movement between Growthpoint and the J203. This confirms the findings of literature in terms of co-movement in the stock market and listed property. It is however evident that there are short periods where differences could be seen more clearly in the 22 day moving averages of Growthpoint's share price and the J203. If the transaction of Growthpoint is considered in terms of the LREIV model, it may be possible to explain some of the movement. Growthpoint indicated that the transaction would be financed primarily by debt and preference shares, which for the purpose of this exercise is also considered as debt, indicating that there should not be a change in equity. This implies that the market capitalisation, and therefore the share price, has a priori expectation to remain constant. According to the LREIV model, the changed long term leverage ratio does however influence the situation. Taking into consideration the expectations regarding the change in Total Assets, Turnover, Operating Profit and Total Cost Shown, it seems that the market capitalisation should be altered by approximately R77,6 million. This represents approximately 0.27 per cent of the total market capitalisation at the time, based on income and expenses for the property that is assumed to be similar to the average of the portfolio, which implies a turnover increase of approximately 12 per cent of the value of the property. Given the size and type of property, this is considered to be unlikely, and therefore the sensitivity for lower levels of turnover and profit figures is also considered. The model shows a zero change in the market capitalisation with a yield of 11.06 per cent, while at an 8 per cent yield, the indication is that the market capitalisation would reduce by R252 million, or 0.87 per cent. The last mentioned figure is considered more likely and therefore it could be stated that a reduction in the share price is expected. 
The above could be an explanation for the underperformance of the Growthpoint share price relative to the $\mathrm{J} 203$ during the timeframe in which the transaction took place, as indicated by the blue shaded area in Figure 1. Soon after completion of the transaction, new shares were issued that changed the market capitalisation due to the number of shares issued and influenced the level of leverage. The latter change and a number of subsequent share issues are also marked by negative changes in the share price. The share price either became lateral or downward moving, which was not all explained by the movement in the $\mathrm{J} 203$.

In conclusion, although it appears that the purchase price of the property was higher than evident in the share price movement and in the individual property attributes, the details available are limited; and more accurate details would enhance the results of the model. Generally share prices are determined by the perceptions of investors, which may be more or less rational. Therefore, some irrationality in the behaviour of investors may also cause short term differences in the results of the model. For more information on the irrational behaviour of investors it is worthwhile to consider behavioural finance (Shiller, 2003).

\section{b Hyprop acquisition of Attfund portfolio}

On 6 December 2010 Hyprop announced that it had in principle reached agreement to purchase the property portfolio of Attfund Retail.

On 21 December 2010, it issued a cautionary announcement regarding the trading of Hyprop units, and provided some financial information on the proposed transaction. On 3 February 2011 the cautionary announcement was renewed.

On 8 April 2011 it was announced that the competition tribunal had approved the transaction. An updated proposal for the transaction with financial effects and forecasts was issued on 13 April 2011, and on 21 April 2011 a circular was posted with full details of the updated transaction, the withdrawal of the cautionary announcement, and a notice of a General Meeting for the shareholders of Hyprop to approve the transaction.

The transaction was approved by shareholders of Hyprop on 13 May 2011. The effective date of the transaction was anticipated for either 1 June 2011, or 1 July 2011, conditional to the implementation of the Attfund Retail restructure.

The share price movement of Hyprop for the period September 2010 to 1 July 2011, which was the anticipated effective date of the transaction, is shown in Figure 2. The blue shaded area highlights the period from the first announcement to the one that the transaction was finally approved. From this it seems as if the Hyprop share price underperformed relative to the J203, but if it is similarly compared to the PLS index (J256) as shown in Figure 3, it is obvious that Hyprop may have slightly outperformed the sector in this time period. After the transaction however, the share price falls back to a very similar pattern to the sector.

By testing the effects of the transaction on the share price, using the LREIV model and the details as provided by Hyprop in the cautionary announcements, the value of the 112000000 shares to be issued, is calculated at R58-00 per share or combined unit. The transaction, however, takes place at R54-00 per share. This suggests that the share price should increase after the transaction due to the positive effect of these higher valued shares. This is assuming the values given for the assets included in the transaction are accurate.

\section{c Listing of the Investec properties portfolio:}

Investec Property Fund Limited (IPF) announced on 6 April 2011 that it would list its portfolio of properties on the JSE, and issued the pre-listing statement containing the financial forecasts for this transaction on the same day. 
Figure 2

Hyprop share price vs All Share Index

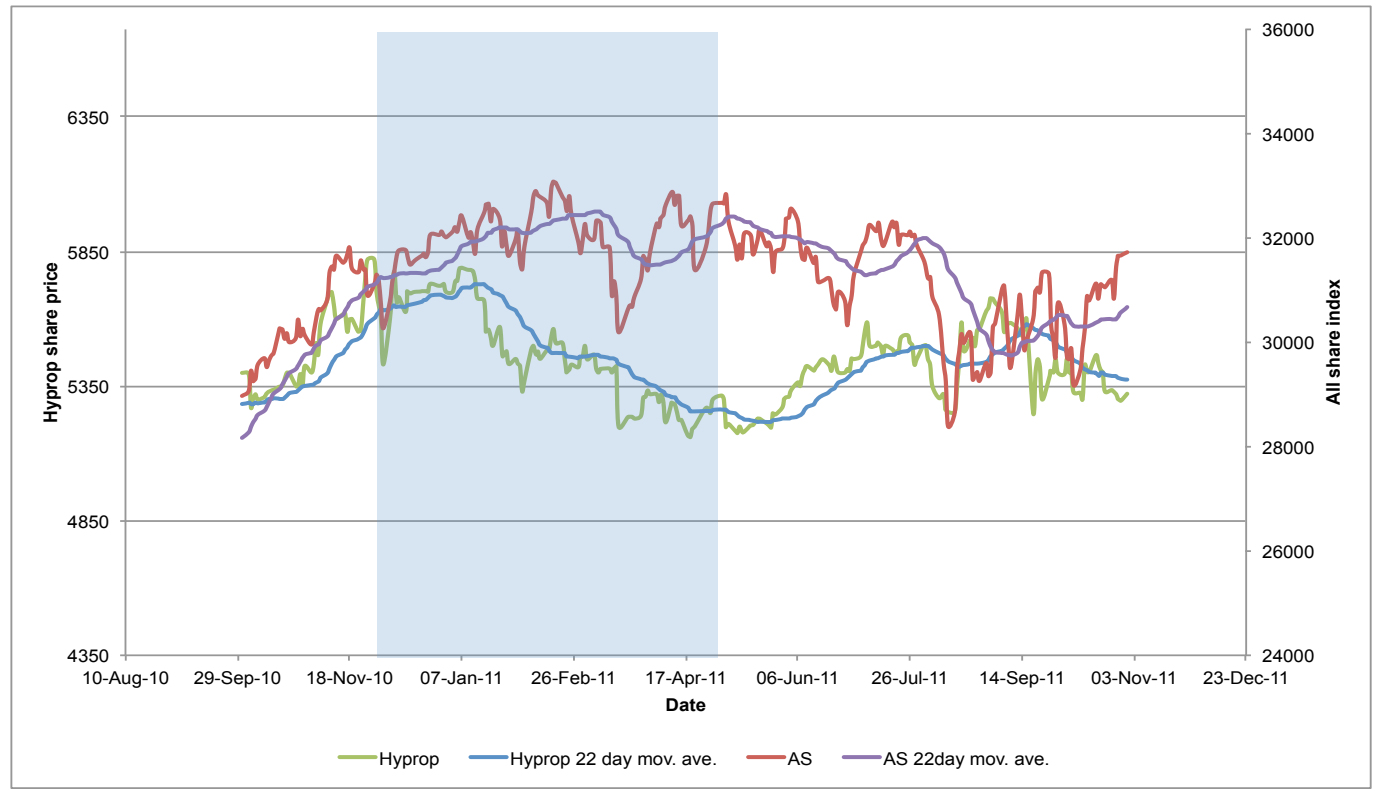

Figure 3

Hyprop share price vs PLS index

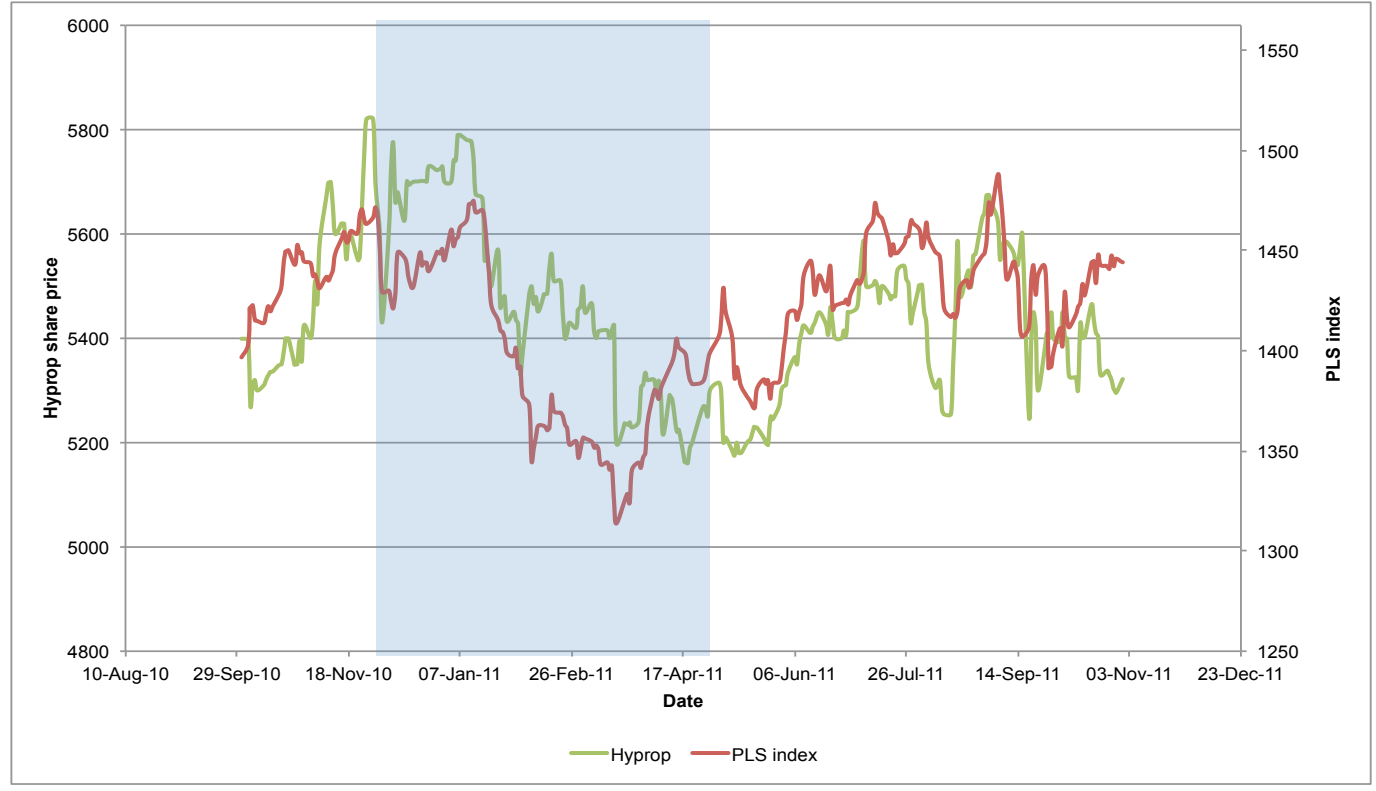

IPF was listed on 14 April 2011, with no debt other than debenture loans. The 170000000 shares were issued at R10-00 for a combined unit, resulting in a total equity position of $\mathrm{R} 1$ 700000000 . The well diversified property

portfolio was valued at the time of listing at R1 696500000 (Investec: 2011).

By testing the pre-listing forecast company structure and financials with the LREIV Model, the share price was estimated to be 
R960. This is assuming that the property values as given by the prelisting announcement are accurate. By comparing the share price performance to the $\mathrm{J} 203$ for the period from listing to 1 year after listing, as shown in Figure 4, it seems that IPF performed slightly better than the J203. Figure 5 compares the IPF share price to the $\mathrm{J} 256$, where it appears that IPF slightly under-performed against the PLS sector for approximately 6 months, and then started to outperform the sector from approximately October 2011. The LREIV model calculated share price of R9-60 against the IPO amount of R10-00 for the shares might explain the initial underperformance against the sector, but in order to explain the change to an outperformance trend, the history of the company was investigated. On 18 October 2011 a shareholders' meeting was held, approving the purchase of another two properties. By testing the effect of this in the LREIV model, it was calculated that the share price should increase by approximately 27 cents. The trend over the few months after the annual meeting revealed that IPF outperformed the sector (if normalised) by approximately 30 to 40 cents.

Figure 4

Investec property fund share price vs All Share Index

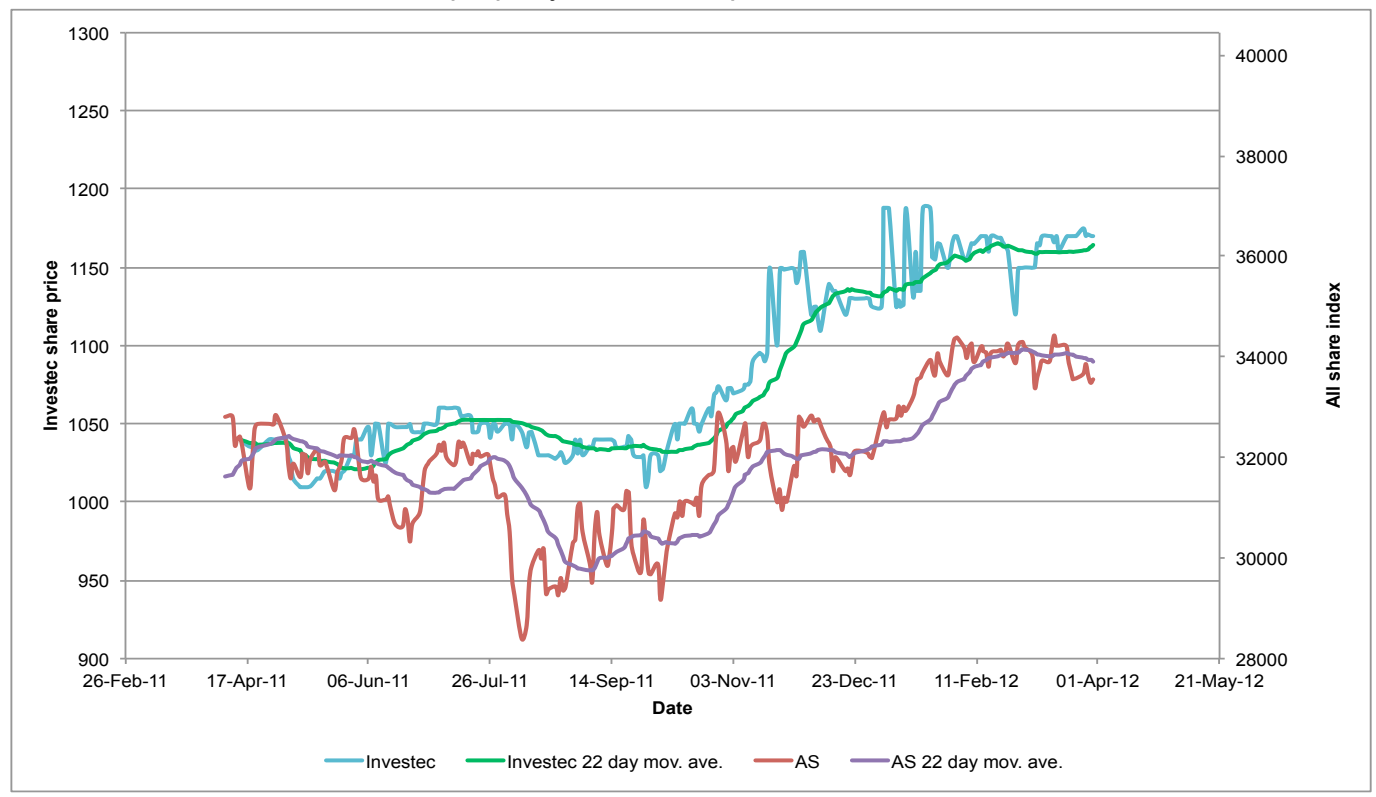

7

\section{Conclusion, shortcomings and recommendations}

The paper investigated the use of financial statement items to predict the share price movement of PLS companies. It was possible to show that approximately 80 per cent of the long term movement in the market capitalisation, and with the number of shares known, the share price could be explained by the variables as shown as the LREIV model. The results found however, that price discovery takes place in the direct property market when annual data is used, which is in contrast to previous research that found price discovery in the listed property market.

In section 6, the LREIV Model was testedon three different examples of recent market transactions. This not only provided some validity to the study, but showed the practical application of the model. 
Figure 5

Investec property fund share price vs PLS index

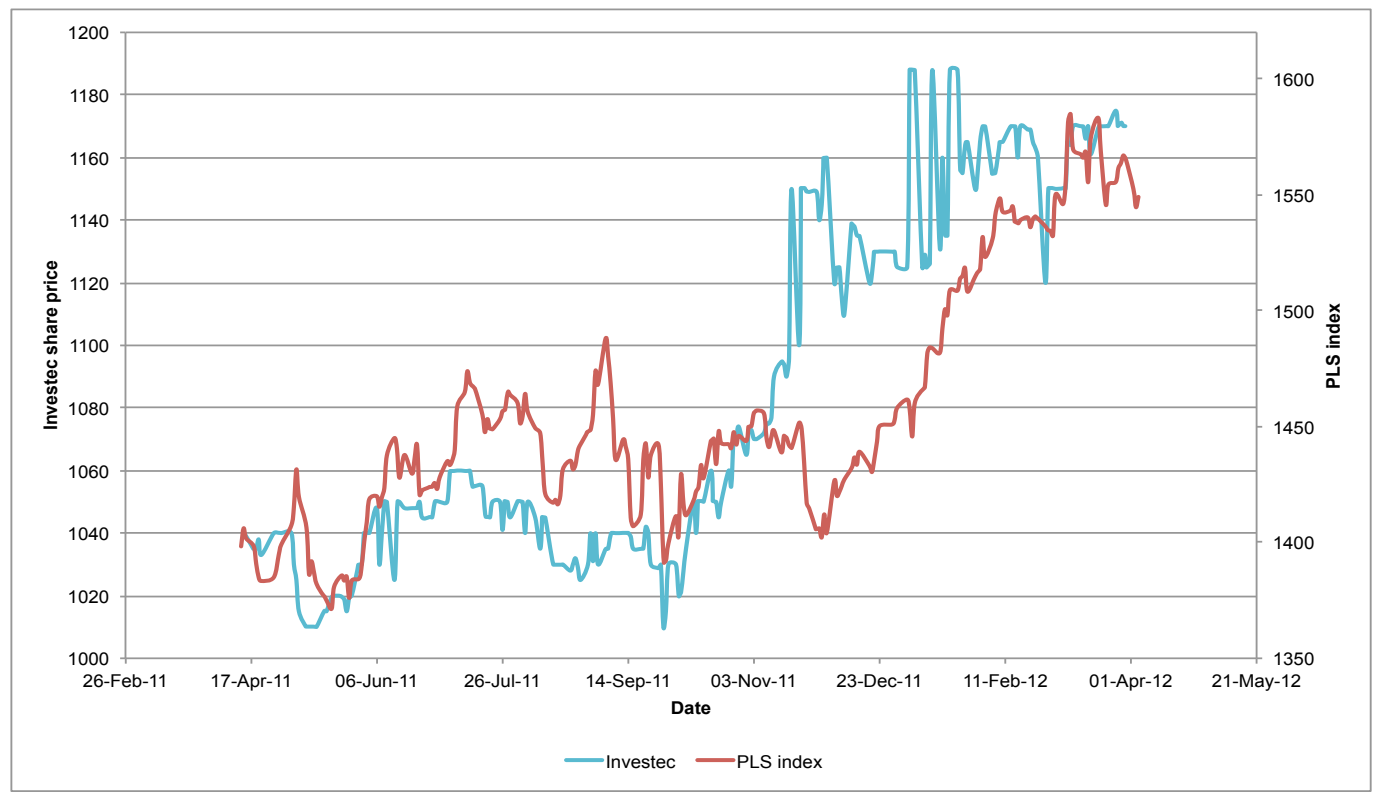

Figure 6

Investec property fund LREIV model regressed vs observed values

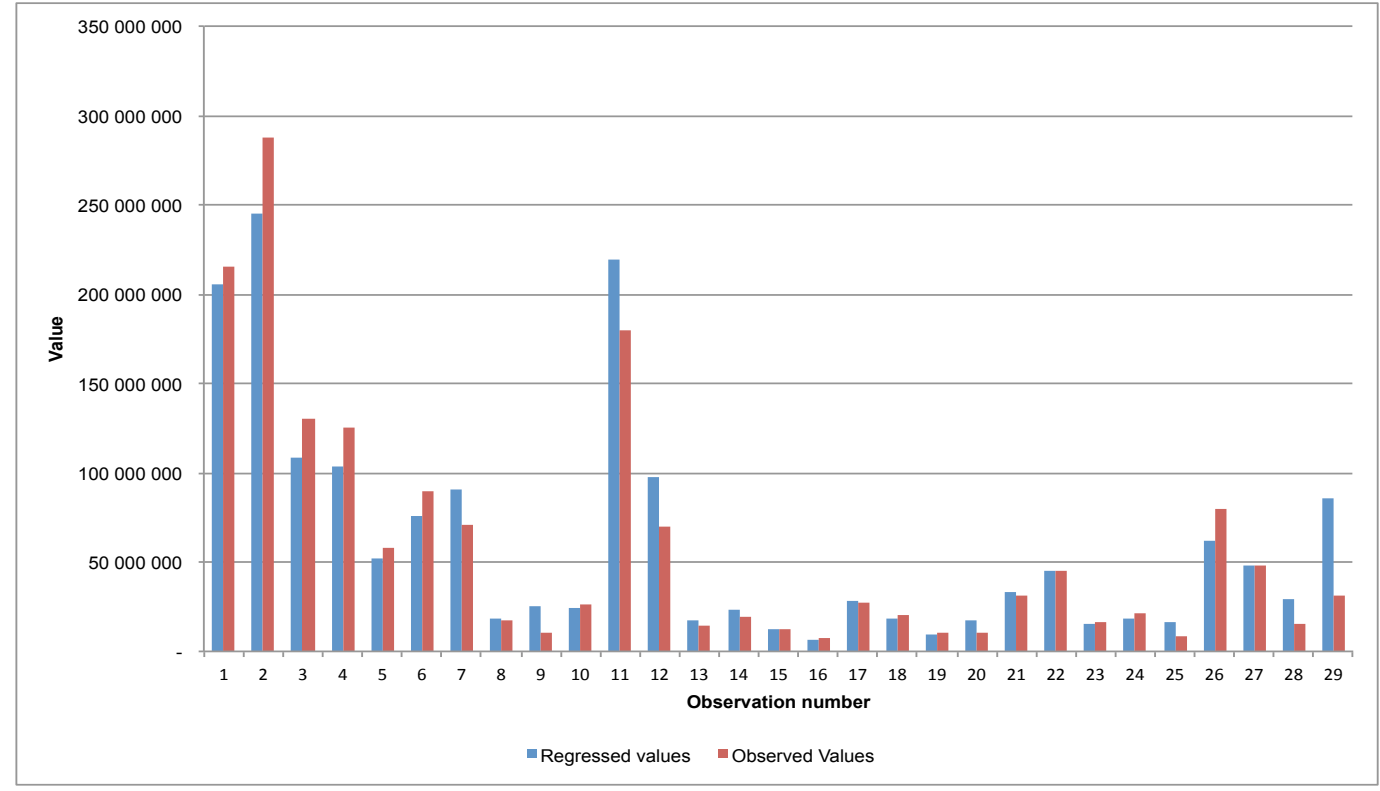

The LREIV model is limited mostly by information availability. It was noted in section 5 that there is evidence of information deficiency, with specific reference to debenture interest paid and to a lesser extent to some

observations of other variables. This is similarly the case with the LREIV model as tested, which is based on information available to shareholders only, in the form of annual data. Although this limitation is evident for 
shareholders or other third parties, it is not necessarily the case for executives of these companies, who have inside information that could be used in the model. The model is however not tested in such an environment and this could therefore not be stated conclusively.

By accepting the alternative hypothesis, the model was formalised in principal form. In order to increase the model's accuracy and credibility it is required to increase the data available for analysis. It is therefore recommended that the model be enlarged with more data, to investigate opportunities of increasing its accuracy.

The study was also limited to PLS companies. It is suggested that further research be performed on the possibilities of applying the model to property unit trust funds as well as real estate investment trusts, as alternative forms of listed property investment.

Furthermore, the study was limited to the South African property market. It is suggested that the applicability of the research be tested on other international markets.

\section{References}

BARKHAM, R. \& GELTNER, D. 1995. Price discovery in American and British property markets. Real Estate Economics, 23(1):21-44.

BOOTH, P.M. \& MARCATO, G. 2004. The dependency between returns from direct real estate and returns from real estate shares. Journal of Property Investment and Finance, 22(2):147-161.

BOUDRY, W.I., COULSON, N.E., KALLBERG, J.G. \& LIU, C.H. 2011. On the hybrid nature of REITs. The Center for Real Estate and Finance: Working Paper, 38 pp.

BRENNAN, M.J. 1990. Latent assets. Journal of Finance, 45(3):709-730.

CHAN, K.C., HENDERSHOTT, P.H. \& SANDERS, A.B. 1990. Risk and return on real estate: evidence from equity REITs, AREUEA Journal, 18(4):431-452.

CHAN, S.H., LEUNG, W.K. \& WANG, K. 1998. Institutional investment in REITs: evidence and implications. Journal of Real Estate Research, 16(3):357-374.

DOPPEGIETER, J. \& RODE, E. 2002. Capitalization rates and property yields: an analysis of the South African commercial property market. Unpublished Working Paper, $17 \mathrm{pp}$.

DOWNS, D.H. \& GÜNER, Z.N. 1999. Is the information deficiency in real estate evident in public market trading? Real Estate Economics, 27(3):517-541.

FISHER, J.D., GELTNER, D.M. \& WEBB, R.B. 1994. Value indices of commercial real estate: a comparison of index construction methods. Journal of Real Estate Finance and Economics, 9:137-164. GILIBERTO, S.M. 1990. Equity real estate investment trusts and real estate returns. Journal of Real Estate Research, 5(2):259-263.

GILLAN, S.L. \& STARKS, L.T. 1999. Relationship investing and shareholder activism by institutional investors: the wealth effects of corporate governance related proposals. SSRN Working Paper Series.

GILLAN, S.L. \& STARKS, L.T. 2000. Corporate governance proposals and shareholder activism: the role of institutional investors. Journal of Financial Economics, 57:275-305.

GLASCOCK, J.L., LU, C. \& SO, R.W. 2000. Further evidence on the integration of REIT, bond, and stock returns. Journal of Real Estate Finance and Economics, 20(2):177-194.

GYOURKO, J. \& KEIM, D.B. 1992. What does the stock market tell us about real estate returns?, Real Estate Economics, 20(3):457-485.

GYOURKO, J. \& KEIM, D.B. 1993. Risk and return in real estate: evidence from a real estate stock index. Financial Analysts Journal, September-October:39-46.

GYOURKO, J. \& LINNEMAN, P. 1988. Owner-occupied homes, income-producing properties, and REITs as inflation hedges: empirical findings. Journal of Real Estate Finance and Economics, 1(4):347-372.

HAGER, D.P. \& LORD, D.J. 1985. The property market, property valuations and property performance measurement. Conference Paper, JIA (112):19-60.

LEE, S. \& STEVENSON, S. 2007. The substitutability of REITs and value stocks. Applied Financial Economics, 17:541-557.

LING, D.C. \& NARANJO, A. 1999. The integration of commercial real estate markets and stock markets. Real Estate Economics, 27(3):483-515. 
LIZIERI, C. \& SATCHELL, S. 1997. Interactions between property and equity markets: an investigation of linkages in the United Kingdom 1972-1992. Journal of Real Estate Finance and Economics, 15(1):11-26. MCGREGGOR BFA. 2009-2011. Available at: <http://www.mcgreggor bfa.com> [accessed January 2009July 2011].

NEWELL, G. \& KENG, T.Y. 2005. Factors influencing the performance of listed property trusts. Paper delivered at the Pacific Rim Real Estate Society Conference 23-27 January 2005, Melbourne, Australia, 22 pp. PETERSON, J.D. \& HSIEH, C. 1997. Do common risk factors in the returns on stocks and bonds explain returns on REITs? Real Estate Economics, 25(2):321-345.

ROSS, S.A. \& ZISLER, R.C. 1991. Risk and return in real estate. Journal of Real Estate Finance and Economics, 4(2):175-190.

SAGALYN, L.B. 1990. Real estate risk and the business cycle: evidence form security markets. Journal of Real Estate Research, 5(2):203-219.

SCOTT, L.O. 1990. Do prices reflect market fundamentals in real estate markets? Journal of Real Estate Finance and Economics, 3:5-23.

WILSON, P.J. \& ZURBRUEGG, R. 2003. Isolating important driving forces in indirect real estate markets. Journal of Real Estate Portfolio Management, 9(3):205-218.

YAVAS, A. \& YILDIRIM, Y. 2011. Price discovery in real estate markets: A dynamic analysis. Journal of Real Estate Finance and Economics, 42:1-29.

Annexure 1

Multiple regression of company data

Descriptive Statistics

\begin{tabular}{|l|r|r|r|}
\cline { 2 - 4 } \multicolumn{1}{c|}{} & \multicolumn{1}{c|}{ Mean } & Std. Deviation & N \\
\hline Average market cap & 432980815.019 & 1101497612.517 & 126 \\
\hline Prime & 11.948 & 2.009 & 126 \\
\hline Total Assets & 710665.473 & 1705619.146 & 126 \\
\hline Deferred Tax & 53026.684 & 163529.957 & 117 \\
\hline Turnover & 66922.280 & 201819.192 & 124 \\
\hline Operating Profit & 70615.576 & 417515.550 & 126 \\
\hline Total Cost Shown & 1520.867 & 41244.040 & 126 \\
\hline Interest Paid - Debentures & 69675.607 & 129470.593 & 68 \\
\hline Leverage - long term\% & .515 & & .237 \\
\hline Equity & 539431.671 & 1426996.169 & 112 \\
\hline
\end{tabular}

Model Summary ${ }^{\mathrm{b}}$

\begin{tabular}{|c|c|c|c|c|c|}
\hline Model & $\mathbf{R}$ & R Square & $\begin{array}{c}\text { Adjusted } \mathbf{R} \\
\text { Square }\end{array}$ & $\begin{array}{c}\text { Std. Error of the } \\
\text { Estimate }\end{array}$ & Durbin-Watson \\
\hline 1 & $.918^{\mathrm{a}}$ & .842 & .815 & 473752574.775 & 1.998 \\
\hline
\end{tabular}

a Predictors: (Constant), Equity, Prime, Total Cost Shown, Leverage - long term\%, Turnover, Operating Profit,

Deferred Tax, Interest Paid - Debentures, Total Assets

b Dependent Variable: Average market cap

ANOVA $^{a}$

\begin{tabular}{|l|l|r|r|c|c|}
\hline \multicolumn{1}{|c|}{ Model } & \multicolumn{1}{|c|}{ Sum of Squares } & df & Mean Square & F & Sig. \\
\hline Regression & 62340158303708600000.000 & 9 & 6926684255967620000.000 & 30.862 & $.000^{\mathrm{b}}$ \\
\hline Residual & 11670958109519100000.000 & 52 & 224441502106136000.000 & & \\
\hline Total & 74011116413227700000.000 & 61 & & & \\
\hline
\end{tabular}

a Dependent Variable: Average market cap

b Predictors: (Constant), Equity, Prime, Total Cost Shown, Leverage - long term\%, Turnover, Operating Profit, Deferred Tax, Interest Paid - Debentures, Total Assets 
Coefficients $^{a}$

\begin{tabular}{|c|c|c|c|c|c|c|}
\hline \multirow{2}{*}{ Model } & \multicolumn{2}{|c|}{ Unstandardized Coefficients } & \multirow{2}{*}{$\begin{array}{c}\text { Standardized } \\
\text { Coefficients } \\
\text { Beta }\end{array}$} & \multirow{2}{*}{$\mathbf{t}$} & \multirow{2}{*}{ Sig. } & \multirow{2}{*}{ VIF } \\
\hline & B & Std. Error & & & & \\
\hline (Constant) & -754633141.199 & 425313750.940 & & -1.774 & .082 & \\
\hline Prime & 45981466.196 & 32107910.050 & .084 & 1.432 & .158 & 1.131 \\
\hline Total assets & 63.686 & 95.330 & .099 & .668 & .507 & 7.185 \\
\hline Deferred tax & 2520.437 & 972.115 & .374 & 2.593 & .012 & 6.868 \\
\hline Turnover & 2621.867 & 805.903 & .480 & 3.253 & .002 & 7.190 \\
\hline Operating profit & 117.726 & 248.572 & .045 & .474 & .638 & 2.927 \\
\hline Total cost shown & -1582.077 & 1556.735 & -.059 & -1.016 & .314 & 1.120 \\
\hline Interest paid - debentures & 3080.487 & 1193.162 & .362 & 2.582 & .013 & 6.486 \\
\hline Leverage - long term $\%$ & 377216472.089 & 288827916.559 & .081 & 1.306 & .197 & 1.274 \\
\hline Equity & -243.110 & 112.149 & -.315 & -2.168 & .035 & 6.961 \\
\hline
\end{tabular}

a Dependent Variable: Average market cap

Annexure 2

Multiple regression of company data - Debenture interest paid and outliers removed

Descriptive Statistics

\begin{tabular}{|c|c|c|c|}
\hline & \\
\hline & Mean & Std. Deviation & $\mathbf{N}$ \\
\hline Average market capSD2 & 299416850.250 & 586145230.963 & 123 \\
\hline Prime & 11.948 & 2.009 & 126 \\
\hline Total AssetsSD2 & 399876.080 & 919188.909 & 120 \\
\hline Deferred TaxSD2 & 24446.293 & 68211.754 & 109 \\
\hline TurnoverSD2 & 32997.394 & 77840.666 & 119 \\
\hline Operating ProfitSD2 & 68394.276 & 197656.980 & 120 \\
\hline Total Cost ShownSD2 & -197.419 & 11472.996 & 121 \\
\hline Leverage - long term\%SD2 & 0.520 & 0.234 & 111 \\
\hline Equity SD2 & 312054.026 & 678474.277 & 117 \\
\hline
\end{tabular}

Model Summary

\begin{tabular}{|c|c|c|c|c|c|}
\hline Model & R & R Square & $\begin{array}{c}\text { Adjusted } \mathbf{R} \\
\text { Square }\end{array}$ & $\begin{array}{c}\text { Std. Error of the } \\
\text { Estimate }\end{array}$ & Durbin-Watson \\
\hline 1 & $.906^{\mathrm{a}}$ & .820 & .804 & 259595336.664 & 2.121 \\
\hline
\end{tabular}

a Predictors: (Constant), EquitySD2, Prime, Leverage - long term\%SD2, Total Cost ShownSD2, TurnoverSD2, Operating ProfitSD2, Deferred TaxSD2, Total AssetsSD2

b Dependent Variable: Average market capSD2

ANOVA $^{\mathrm{a}}$

\begin{tabular}{|l|r|l|r|c|c|}
\hline \multicolumn{1}{|c|}{ Model } & \multicolumn{1}{|c|}{ Sum of Squares } & \multicolumn{1}{c|}{ df } & Mean Square & F & Sig. \\
\hline Regression & 26775884742060500000.000 & 8 & 3346985592757560000.000 & 49.666 & $.000^{\text {b }}$ \\
\hline Residual & 5862907277136060000.000 & 87 & 67389738817655800.000 & & \\
\hline Total & 32638792019196600000.000 & 95 & & & \\
\hline
\end{tabular}

a Dependent Variable: Average market capSD2

b Predictors: (Constant), EquitySD2 , Prime, Leverage - long term\%SD2, Total Cost ShownSD2, TurnoverSD2, Operating ProfitSD2, Deferred TaxSD2, Total AssetsSD2 


\section{Coefficients $^{\mathrm{a}}$}

\begin{tabular}{|c|c|c|c|c|c|c|}
\hline \multirow{2}{*}{ Model } & \multicolumn{2}{|c|}{ Unstandardized Coefficients } & \multirow{2}{*}{$\begin{array}{c}\begin{array}{c}\text { Standardize } \\
\text { d }\end{array} \\
\text { Coefficients } \\
\text { Beta }\end{array}$} & \multirow{2}{*}{$\mathbf{t}$} & \multirow{2}{*}{ Sig. } & \multirow{2}{*}{ VIF } \\
\hline & B & Std. Error & & & & \\
\hline (Constant) & -427453520.992 & 187806016.175 & & -2.276 & .025 & \\
\hline Prime & 30947161.307 & 14075496.979 & .106 & 2.199 & .031 & 1.127 \\
\hline Total AssetsSD2 & -160.427 & 73.192 & -.252 & -2.192 & .031 & 6.381 \\
\hline Deferred TaxSD2 & -2896.922 & 611.889 & -.337 & -4.734 & .000 & 2.456 \\
\hline TurnoverSD2 & 1149.176 & 462.045 & .153 & 2.487 & .015 & 1.824 \\
\hline Operating ProfitSD2 & 689.365 & 174.508 & .232 & 3.950 & .000 & 1.677 \\
\hline Total Cost ShownSD2 & 2638.330 & 2548.489 & .052 & 1.035 & .303 & 1.205 \\
\hline Leverage - long term & 201149167.230 & 122614791.361 & .080 & 1.640 & .105 & 1.156 \\
\hline EquitySD2 & 970.870 & 103.879 & 1.124 & 9.346 & .000 & 7.002 \\
\hline
\end{tabular}

a Dependent Variable: Average market cap 